\title{
A Political Genealogy of Dance: The Choreographing of Life and Images
}

\author{
Julian Reid \\ Faculty of Social Sciences; University of Lapland; 96300 Rovaniemi, Finland; reidjulian@gmail.com
}

Received: 3 May 2018; Accepted: 25 June 2018; Published: 28 June 2018

\begin{abstract}
This article provides a genealogical critique of the history and modernity of dance. In doing so it establishes the political importance of dance as an art not principally of the body and its biopolitical capacities for movement, but of images and imagination. It traces the development of dance as an art of imagination, lost and buried in the works of Domenico da Piacenza, Jean-Georges Noverre, and Loïe Fuller, as well as its counter-movement expressed in the work of Rudolf Laban. It also locates contemporary dance within this political conflict by exploring new works, especially those of Ivana Müller, which call upon beholders to use their imaginations through the evocation of histories and memories. Such works can be understood to be deeply political, it will argue, because they work to transform society by creating time for a belief in the impossible. At its best, dance does not simply incite bodies to move but suspends movement, transforming the very image of what a body is capable of. These aims and practices of dance speak to contemporary concerns within political practice, theory, and philosophy for a reawakening of political imagination in times of crisis and neoliberal hegemony.
\end{abstract}

Keywords: dance; choreography; life; image; imagination; movement; power; genealogy; biopolitics

\section{Introduction}

This article concerns the political genealogy of dance. In what sense, if any, can we call dance an art of the political? How have power relations shaped the historical development of dance and how has its development functioned to alter arrangements of political power? What kind of politics does dance enable us to imagine or does it simply serve to reinforce dominant images of power? How does dance connect up with other practices and theories concerned with the choreographing of power in political philosophy?

Every genealogy of dance, as of every other object, is inevitably partial and singular. In addressing dance this article will be dealing simply with western aristocratic and theatrical dance, without taking into account non-aristocratic and non-western dance, or popular dance of the modern period. To create a genealogy of the whole of dance history would require much more extensive study than is possible here. This article will also be singular in its aims, in terms of the nature of what it searches for within dance history. In contrast with previous attempts to genealogize dance (Jarvinen 2014; Burt 2004), I seek to theorize the concept which dance contains within itself, of itself, as a political art of image-making, and connect that with the image of dance in political philosophy, showing how important this image has been to trends within contemporary political philosophy concerned with the problem of what various political philosophers have theorized as 'the life of images'. Dance and philosophy support each other, I will argue, in the endeavor of operating upon the present, and transforming the real by acting upon it, impregnating it with images drawn from the past, which might now take on the future, in a movement which it is the task of political genealogy itself to create-one which dispels nostalgia, conquers melancholy, and is neither happy nor sad, but affective. 
Of course, throughout the modern era dance has served to reinforce dominating images of power, including those of 'monarchy, national identity, gendered identity, racialized identity, and ritualized identity' while also demonstrating 'the ability to stand apart, acting as a critical theory of society' (Franko 2006, p. 4). 'The body in motion' has been choreographed in projection of virtually every national identity of the modern era while the questioning and exposure of the function of the body and its movements in the choreographing of political power has been the task which dance has set itself wherever it has sought to be subversive and critical (Franko 2006, p. 6). In essence, these are the stakes in which dance has been understood to be political by those concerned with its politics-as an art which partakes in a wider struggle over and for the significance and meaning of the body and its capacities for movement. Is there any sense, however, in which dance can be found to problematize the centrality of the body to politics, both in its conservative and oppressive forms, and in its subversions of those very regimes? In what ways, if any, does dance problematize movement as a property of bodies and their politics? Is dance an expression, in other words, of what Michel Foucault has enabled us to see as biopolitical modernity, or is it a source of opposition to biopolitics?

\section{An Art of Images}

This article traces the ways in which amid the historical development of dance there emerged an attempt to construe dance not as an art of the body and its movement, either in support of or in contestation of political power, but as an art which pitches itself against the body and which seeks to free the image of movement from its ties to the body. Of all the arts, dance is arguably the most fundamentally engaged in the problem of the biopolitical. Much of dance has of course involved attempts to foreground and materialize the body. It is represented as existing in overlap with the field of somatics, and practices dedicated to reifying the body, the potency of bodies, and the 'love of movement and curiosity about the physical body' (Eddy 2009, p. 6). However, its history and present development also entails important attempts, I will argue, to struggle against the body. The history of dance is a history of both these impulses; to foreground and materialize the movements of which bodies are capable, as well as to free the image of movement from its ties to the body.

Because so much of the scholarship and literature around dance have represented it as an art of and for the body, this article addresses the latter impulse and the other strand within dance history, whereby exponents of dance have attempted to free the image of movement from its prison of bodies and their capabilities. This was evident explicitly in the 19th century in the art of Loïe Fuller and especially her 'Serpentine Dance'; heralded by the art critic Paul Adam in 1893 as a 'new art' itself emergent 'from a new body, relieved of the weight of its flesh, reduced to a play of lines and tones, whirling in space' (Ranciere 2013, p. 94). The poet Mallarmé was, as we will see, to make similar claims for Fuller's novelty. Contemporary theorists of dance, such as Tom Gunning, and the philosopher Jacques Rancière have made convincing reiterations of this thesis (Gunning 2003; Ranciere 2013). Dance is, in essence, neither simply an art of the body or simply of movement as is commonly supposed, nor is it an art simply of time as it has otherwise sometimes been argued (Agamben 2013, p. 10). It is an art principally of images and their choreography. The history, however, of how dance became an art of images, pitched against the body, has yet to be recovered or explicated. It did not simply begin, in the late 19th century, with Fuller and the wider phenomenon of serpentine dancing, as is sometimes supposed. At the very least we have to contextualize the development of Fuller in a deeper history, one which makes sense of the relations of her art not only to the 18th century works of the French choreographer, Noverre, but to the very first treatise on dance, written in the 15th century, by Domenico da Piacenza, who taught dance at the court of the Sforza in Milan (Thesiger 1973, p. 283). While Rancière will help us piece together relationships of Fuller to Noverre, we will also draw from recent work by Agamben to situate both Fuller and Noverre in genealogical relationships to Domenico. All of this indicates the importance of the image of dance in philosophy itself for the development of the function of imagination in dance. 


\section{Domenico da Piacenza and Dance as Art of Phantasmata}

Giorgio Agamben's relatively recent tract, Nymphs, addresses the origins of the modernity of dance, and in doing so, focuses on a much neglected text which is nevertheless of fundamental importance for the genealogy of dance as a political art of image making, On the Art of Dancing and Choreography, by Domenico da Piacenza (Agamben 2013, pp. 6-10). Writing in the 15th century, Domenico detailed six fundamental aspects of the art of dance: measure, memory, agility, manner, measure of the ground, and phantasmata (Agamben 2013, p. 7). To date, it is the aspect of measure which scholars have focused on to define Domenico's theory of dance (Thesiger 1973, pp. 282-84). Yet phantasmata were just as important Domenico maintained. Phantasmata are the products of what the Greeks called phantasia; the function of the spirit which we now name imagination (Braga 2010, p. 2). They were of key importance, Domenico held, for the art of dance. "Note that whoever wants to learn the art, needs to dance according to phantasmata" he wrote (Smith 1995, p. 13).

Phantasmata do not, for Domenico, however, refer simply to images. Phantasmata is a 'physical quickness' the control of which necessitates that 'at each tempo one appears to have seen Medusa's head ... and be of stone in one instant, then, in another instant, take to flight' (Smith 1995, p. 13). Such a definition of phantasmata as 'physical quickness' might seem odd, or at least at variance from traditional understandings as being simply products of imagination. However, when we consider the observations of the function of phantasmata in the behavior of the possessed, such as those said to have been afflicted with phantasmata in the convent of Loudon, we discover how their function was said to induce 'an astonishing quickness ... such quickness and violence, that no one in the world, however agile the person might be, could do anything approaching to it' (Madden 1857, p. 291). Phantasmata, in other words, are to be understood as a particular kind of image, inductive of a speed of bodily movement, but which unlike in their function within the possessed, can in turn, be controlled and measured, such that the body alternates between a stone-like stillness and bird-like flight. 'The true locus of the dancer is not the body and its movement but the image as a "Medusa's head, as a pause that is not immobile but simultaneously charged with memory and dynamic energy" (Agamben 2013, p. 10).

\section{Noverre and Dance as a Living Image of the Passions}

Writing in the 18th century, the French choreographer, Jean Georges Noverre, in his letters, which, as an exposition on the theories and laws governing dance, are said to have no equal (Beaumont 2004, p. xi), also embellished the relation between dance and imagination. Writing on ballet, he described how 'a ballet is an image, or rather a series of images connected one with the other by the plot which provides the theme of the ballet' (Noverre 2004, p. 9). However, Noverre's mission was to revolutionize such a conception of dance as a mere provider of images for plots, declaring himself charged with the task of 'devising ballets with action' in order to 're-unite action with dancing' (Noverre 2004, p. 10). A scene d'action, according to Noverre, should be 'full of fire ... where the dance should speak with fire and energy; where symmetrical and formal figures cannot be employed without transgressing truth, without enfeebling the action and chilling the interest' (Noverre 2004, p. 13). A well-composed dance, in Noverre's terms, was one that does not merely provide images with which to tell preconceived stories, but which is 'a living image of the passions' (Noverre 2004, p. 16). An image which 'lives', in Noverre's view, is one that contains within it many different gradations, many different oppositions, variations of light, and shades to observe' (Noverre 2004, p. 13). In this context he argued against the conventions of 18th century dance which held that any one dance should depict just two images only, and that these two images should be symmetrically opposed and unvarying in their nature. An example which Noverre gave was that of where a band of nymphs which:

... at the unexpected sight of a troupe of young fauns, takes flight hurriedly in fear; the fauns, on their side, pursue the nymphs with eagerness, which generally suggests delight: presently, they stop to examine the impression they have made on the nymphs; at the same 
time the latter suspend their course; they regard the fauns with fear, seek to discover their designs, and to attain by flight a refuge which would secure them against the danger which threatens; the two troupes approach; the nymphs resist, defend themselves and escape with a skill equal to their agility (Noverre 2004, pp. 12-13).

Such a choreography of two images only, where one expresses the desire of the fauns, and the other that of the fear of the nymphs, makes, Noverre argued, for a 'cold and formal performance' (Noverre 2004, p. 13). In contrast, and against this tradition of symmetry and contrived opposition, Noverre pitched his principle of action; so that from any two passions, be they fear and desire say, there results 'a multitude of images, each more animated than the other' (Noverre 2004, p. 13). Only then could we speak, he argued, of an art of dance in which images 'live' a life of truth through the affirmation of their multiplicity, their inventiveness, and capacities for endless variation.

The role of the concept of image has been largely missed in the critical reception of Noverre's work, right up until the present day. For historians such as Jocelyn Powell, Noverre was simply a naturalist, working in alliance with other naturalists of the period throughout the dramatic arts, to enable art to approximate to nature better (Powell 1988). Rancière, in his Aisthesis, describes well the ways in which Noverre's theory offered a 'revolution in representative logic ... opposing the organic model of action as body, ideal proportion, and the entire system of conventions linking subjects to genres and modes of expression' by seeking a more 'direct expression of emotions and thoughts' (Noverre 2004, pp. 6-7). Nevertheless, like Powell, he fails to identify in Noverre's revolutionary manifesto for dance the centrality of the role of images. In contrast to the traditional story-telling function of the images created by dance, Noverre opposed, as Rancière well describes, 'an art in which every bodily gesture and every grouping of bodies tells a story and expresses a thought' (Noverre 2004, p. 7). At stake in this opposition of Noverre to the traditional story-telling function of dance was what would develop historically into a 'new idea of fiction' (Noverre 2004, p. 100). One that substitutes plot 'with the construction of a play of aspects, elementary forms that offer an analogy to the play of the world' (Noverre 2004, p. 100). The point, however, is that this revolution was testimony also to an emancipation of the life of images in dance; an emancipation of the image from its status in subordination to narrative, giving privilege to the life of the image as the object of dance as such.

\section{Fuller and Dance as the Pure Play of Images}

It was in the 19th century choreography of the American, Loïe Fuller that Rancière saw the development of such a new idea of fiction coming to a greater fruition. Fuller was famous for her Serpentine Dance in which her body remained static while the long dress she wore was swirled in creation of a play of lines which, in turn, 'draw the shape of a butterfly, a lily, a basket of flowers, a swelling wave, or a wilting rose' in a 'pure spinning, spirals and swirls centered and guided by her body (Ranciere 2013, p. 95). The Serpentine entailed the rejection of the kind of classical model of beauty, based on symmetry and proportion, which Noverre's choreographic manifesto had also encouraged. The Serpentine represented, as Rancière describes, 'the destruction of the organic as the natural model of beauty' by opposing a 'perpetual variation of the line whose accidents endlessly merge' against the 'order of geometric proportion' (Ranciere 2013, p. 95). The static nature of Fuller's body, suborned to the spinning and swirling activities of her dress veiling it, also represented, following Rancière, 'the potential of a body by hiding it' (Ranciere 2013, p. 96). Her dress was 'the supplement that the body gives itself to change its form and function (Ranciere 2013, p. 96).

Fuller's art entailed 'the invention of a new body' whereby the body becomes a 'dead center in the midst of movement', engendering new forms through its staticity. Such forms, be they that of a butterfly, a lily, a basket of flowers, a wave or a rose, are not characters in a story that Fuller's dance helps tell. Their movements do not enjoin in an operation of plot making. Instead, they represent a new idea of fiction as a 'pure display of a play of forms', abstract, in so much as it tells no story, but instead tell only the event of their apparition (Ranciere 2013, p. 100). However, for Fuller's Serpentine Dance to be understood, and for its importance in the historical development of the art of dance to be 
appreciated, the role of images has to be addressed. For what her dance did was to turn the body into a site for the creation of a pure play of images, engendering new imaginary forms in ways that spoke directly to Noverre's demand that dance become an art for the creation of a 'multiplicity of images' (Noverre 2004, p. 13). In fact, Fuller's dance went, at the very least, one step further than that incited by Noverre, for what is masterly in the Serpentine Dance is that she not only makes images dance, but that she creates one particular image, that of a veil. Rancière supposes that her dress functions as a veil (Ranciere 2013, p. 96). In fact it is only an image of a veil. We know of course that her body is within the dress. However, a veil, for it be veiling, must function to hide something that incites us to ask what is behind it. Fuller's dress does not hide her body, or incite us to ask that question. For we already know the answer to the question of what is veiled by it; her veil is purely an image that dances.

Long before Rancière, Fuller inspired the poet Mallarmé, who described likewise the ways in which her practice, 'an invention without utility', caused a fading away of the 'imbecility' of the traditional placing of permanent sets in opposition, by dint of her 'choreographic mobility' (Mallarmé 2001a, pp. 114-15). Rancière's account of how Fuller's art worked to destroy the tyranny of such rules of symmetrical proportion within dance and choreography is in many ways only a supplement to Mallarmé's much earlier account. Indeed, in Mallarmé's wider writings on dance we can find an account of dance as an art of images in ways very much in accordance with what I am arguing here. 'The sole imaginary training consists', he wrote, 'during these ordinary hours frequenting the world of dance, of wondering before each of these strange steps, each of these strange attitudes, these points and taquetes: "what can this mean?' Dance transports us to a world in which we 'function in full daydream', where 'the poetic instinct' reigns, providing 'revelation in its true light of thousands of latent imaginations' (Mallarmé 2001b, pp. 112-13)".

This is not to argue that the body is not nevertheless present in Fuller's art. As Ann Cooper Albright has convincingly argued, 'Fuller's body is undeniably present' (Albright 2007, p. 5). Addressed in its entirety Fuller's art encapsulates the great paradox of dance as I see and explore it here, in so far as it deploys the body in order to vaporize the body, suborning it to the image. Others, Cooper Albright included, may well interpret her art as a different kind of attempt to foreground the body in dance. Fuller's legacy was expressed historically in the development of dance through path-breaking works of the 20th century, including, notably, those of Isadore Duncan and Mary Wigman. She is often described as having 'modernized' dance through her execution of new ideas concerning stagecraft, music, and scene design (Sommer 1980, p. 389). However, as Rancière argues, Fuller's work remains, in spite of that, in actuality, outside of the modernity of dance. It cannot be reconciled with the expressionism of Duncan and Wigman, both of whom sought, in their practices and performances, to manifest a total expression of every movement of which a body is capable (Ranciere 2013, pp. 104-5). Fuller, in contrast with those who followed in her wake, was not concerned with mapping the body, revealing each of its different potentials, but with subordinating the body to the life of images. For Fuller the body was not the subject of dance. Nor movement. In contrast, the body operates within her work as a mere instrument for the creation of endless imaginary forms. It is in that sense that she subordinated the body within dance to a life of images—a point missed in Rancière's otherwise illuminating analysis. She was, in this sense, more true to Noverre's 18th century ambitions for the modernity of dance; that it should become an art given over to the life of images. The body itself, we might say, was transformed in her work, into a font for a multiplicity of images, irreducible to bodily movement or even the body itself. Her body expressed nothing of its inner movements. Instead her body created purely imaginary forms that existed outside of it. The movement of those images, while in some sense depending on her body, nevertheless did not belong to her body.

\section{Laban and Dance as the Disciplining of Images}

Fuller's legacy might well be seen in the development of the work of artists such as Alwin Nikolais whose Tensile Involvement, which premiered in 1953, for example, freed dance in a similar way as that of Fuller, from the body, moving the gaze away, to abstract shapes (Thompson 2004, pp. 159-60). On the 
whole, however, Fuller's influence would become weaker, with the onset of the modernity of dance as it has been known and established. In the middle of the 20th century, Rudolf Laban, in his celebrated work, The Mastery of Movement, wrote of the need for dancers to use their imaginations but not with a view to dancing in creation of images. Indeed Laban wrote of the need for dancers not simply to use their imaginations but to train them (Laban 2011, pp. 22-24). Laban is often regarded within dance theory and the history of choreography as having contributed to the increasing experimentalization of the art and especially to a privileging of improvisation as a method (Carter 2000, p. 184). The truth is more ambiguous. A disciplining of imagination is what Laban inaugurated within the late 20th century development of dance; in ways that overturned Noverre and Fuller's wishes for it. The body remained, in the work of Laban, an instrument for the expression of 'mood and inner attitude' (Laban 2011, p. 22). Imagination in this context, following Laban, was also to be utilized as a means towards the expression of the body's inner movements. The movement and energy of images, that which concerned Domenico as much as it did Noverre and Fuller, was altogether lost in the standardization of the concept of human movement which Laban achieved whereby human movement was always to be understood as bodily movement. Understanding what I propose to call choreographic life requires, in contrast, following the lost modernity of dance still latent within the forgotten genealogy of dance buried in the works of Domenico, Noverre, and Fuller. Their idea, of images themselves, as 'charged' with autonomous powers to render still, to fix movement, as well as to mobilize and dynamize, is crucial for an understanding of the life of images. It does not merely concern the role of the image in dance, or the disposition of dancers towards images, but the life of images as such. Nevertheless, the art of dance and choreography is a powerful source of thinking and performativity for the development of a theory of the life of images.

\section{The Contemporary Return to Dance as an Art of Images}

One can see the concern of dance with images expressed, once more today, in a contemporary turn within dance itself towards the development and performance of works that, as Ramsay Burt has argued, call upon beholders to use their imagination through the evocation of histories and memories. Such works, Burt argues, are deeply political, because they 'have the potential to transform society by creating time for a belief in the impossible' (Burt 2009, p. 442). Perhaps nowhere is this more strongly expressed than in Ivana Müller's recent performance piece, While We Were Holding It Together (Müller 2012). As Maaike Bleeker has argued convincingly, the piece transforms movement itself, rendering it an element of perception, rather than being something 'out there' which we perceive (Bleeker 2012, p. 67). In Deleuzian terms, the piece performs the mobility of images, showing us not simply images of movement, but inducing the movement of which images alone are capable (Deleuze 1986, 1989). It entails bodies. Indeed, bodies are indispensible to the performance, but they are deliberately and consistently immobilized into statuesque forms. For the duration of the performance, five bodies stand or sit motionless on stage, apparently frozen in poses of different kinds, while verbally articulating what they each imagine their particular pose to signify. Each pose adopted generates a multitude of different imaginaries or imaginative acts. The pose of the body is subordinated to the articulated imaginary. Thus what the audience witnesses in the performance is the operation through which images transform bodies, in spite of their apparent stasis, choreographing them in time, moving them according to the powers of the image each time created. It is in other words a celebration of the superior power of the image over the body, the life of the imagination, and the choreography of images, in ways that speak back historically to the lost legacies of Noverre and Fuller. Müller's performance forces us to understand and grasp the contemporary politicization of dance and choreography, as an art of the image; celebrating its emancipation from its traditional subordination to corporeal movement. The images in While We Were Holding It Together do not simply incite movement in the manner understood as fundamental in Domenico's treatise, they transform the very image of bodies. 


\section{The Image of Dance in Philosophy}

However, it is not enough simply to address dance as an art of the image. Instead we have to address the image of dance in philosophy. For dance itself is an image. Numerous philosophers before us have attempted to enlist the image of dance to enhance their own concepts of life and of movement. As Claire Colebrook has already detailed, in many traditional modes of philosophy dance figures as a meaningful movement only so far as it occurs within an already imagined form of life (Colebrook 2005, pp. 5-8). For this reason, Colebrook has tried to reimagine dance as a movement without ends, such that it precludes any appropriation by philosophy (Colebrook 2005, p. 5). I believe, on the other hand, while recognizing this conflict over the image of dance, that we can nevertheless make a particular image of dance; the image of the movement of images. We know, if we follow Gaston Bachelard, that there is an image of flight, and that this image, involving ascent from the earth, is integral to the psychic life of the human (2002). More integral than flight is this image of dance, which is to say this image of the movement of images. Because dance is the movement through which images themselves are choreographed by humans in time, dance must be construed as the image of the movement of the image. It is not one movement among other movements. It is the primary form of movement to which all images are beholden. It is literally how images move and are moved. The task of dance, as an art form, is to evoke this. More fundamental still is the fact that in our choreographing of images we are all called upon to dance all the time. Flight, following Bachelard, is a superior image. It is the highest image. It is the image which gives rise to human elevation. Nevertheless it is only an image among images. The image of flight, in particular, cannot be distinguished other than in its relation with the image of the fall (Bachelard 2002, pp. 91-109). Dance is different. It is neither an image of elevation or of gravity, but of the choreography of time through which the distinction between movements of fall and flight are erased. If we think the image in this way, then, we are no longer faced with the question of how to make rise that which has fallen, but how to dance such that our falling itself becomes reconciled with the choreography of moves through which we transform our bodies.

\section{Badiou and Dance as Aerial Earth}

In a beautifully written chapter of his book, Handbook of Inaesthetics (Badiou 2005), Alain Badiou describes something of this paradox of dance. He does not engage Bachelard, but instead, Nietzsche's concept of dance. Nevertheless much of what he has to say about dance could as well be accredited to Bachelard. 'Dance', following Nietzsche, Badiou argues, 'is a body that forgets its fetters, its weight' and in being so 'dance is what allows the earth to name itself "aerial"' (Badiou 2005, p. 57). The fundamental question of dance, he argues, is that 'of the relation between verticality and attraction' (Badiou 2005, p. 58). The place of these two forces in the body which dances, we are to suppose, if we follow Badiou's reading of Nietzsche, allows it 'to manifest a paradoxical possibility: that the earth and the air may exchange their positions, the one passing into the other' (Badiou 2005, p. 58).

Badiou recognizes that this is not simply a definition of dance, as if dance existed outside of history, but merely an 'image of dance' (Badiou 2005, p. 59). One can as easily conceive dance, as Laban and many others within the history of modern dance have done, as an 'external constraint imposed upon' an otherwise supple body ... 'a regime of the body in which the body is exerted for the sake of its subjection to choreography' (Badiou 2005, p. 59). There is a risk also in privileging the aerial and the vertical, in dance and other terms, of glorifying a specifically western aesthetic at expense of others, especially the more ground-based aesthetics of Africanist dance practices, for example (Welsh 2004, p. 34). Nevertheless, as Badiou makes clear, Nietzsche, as much as we might suppose Bachelard, participates in the struggle between these different and opposed images of dance, which are as much a part of western dance history as is the history of the image of dance within western philosophical thought. Any image of dance that entails a submission of the body to a preconceived choreography, a la Laban, is not, as far as Nietzsche was concerned, dance at all. It is more akin to the militarized body of the western way of war (Badiou 2005, p. 59). Dance, in contrast, is the aerial body, the vertical body (Badiou 2005, p. 59) otherwise celebrated in Bachelard's work. 
The power of the image of flight can also be literal of course. In 1987, the West German teenager, Mathias Rust, flew his one-engine Cessna aircraft out of Helsinki and into Soviet air space, landing eventually, in Moscow's Red Square. "I wanted to build an imaginary bridge between East and West", he said later, in explanation of his actions. Rust would spend over a year in a Soviet labor camp, but his literal flight of imagination led to the firing of two of Gorbachev's main opponents of his Perestroika reforms, the Defense Minister, and Air General, and it could well be argued that this made a significant contribution to the end of the Cold War, culminating as it did not long after, in the fall of the Berlin Wall, and collapse of the Soviet Union.

Rust's flight is celebrated in a homage performance, Uberflieger, by the dance artist Katja Dreyer (2011) who also appears in Müller's While We Were Holding It Together. The piece aestheticizes the political work which the image of his flight performed, detailing as it does, also, the artist's attempt to make contact with Rust and involve him in the performance; an invitation he declined. The piece conveys the disconnection between spaces in which images of flight circulate, in art, in politics, in the psyche, and in the air, while nevertheless expressing the fundamentality of connections between these spaces. It matters little that Rust does not appear in conversation within the piece, or maybe it matters more that he does not. The strongest of solidarities between spaces is often not only imagined but silent.

Something similar might be observed in the relations between dance and philosophy itself. Bojana Cvejić has argued that Badiou theorizes dance as if 'dance doesn't exist empirically' (Cvejić 2015, p. 13). It is true that his text on dance contains no reference to actual works of dance, only engaging with what Nietzsche and Mallarmé have had to say about dance within the debate over the image of dance in philosophy itself. The same observations could be made of Nietzsche and Bachelard, although neither of them were involved in any dispute over the image of dance, and simply employed their own images of it, as flight. Likewise, of course, much of the art within dance that has been working to produce dance as an art of the image, as well as to produce particular images of dance, has done so without resort to explicit support from philosophy either. Do these apparent disconnections not nevertheless contain within them the quietest of solidarities? Do they not testify to the imaginal qualities of a bond?

\section{Agamben and the Life of Images}

To reground dance as an art of images, an art of movement, but not of the body, instead of the movement of images, and as an art which struggles against the body, is nevertheless to reground dance as an art of life; the life of images, or imaginal life. Images themselves however are ambiguous when it comes to our own lives. As much as an image may give us life, so may it as well take our life. How, as Agamben asks, do we turn an image that arrests our life into an image that charges us with life, such that time itself is reset, and put back into motion? 'There is a life of images that is our task to understand', as he expresses it, in Nymphs (Agamben 2013, pp. 4-5).

Domenico da Piacenza, the great choreographer of the 15th century, understood this task to be fundamental to the art of dance. Domenico described images not only as that which the dancer must learn to control and measure in order to master the art, but as entities equipped with a particular power; the power of arrest (Agamben 2013, p. 8). What determines the relative mastery of the dancer is her ability to confront and subsume images while surviving this power which images would otherwise subject her to, such that she is able to keep moving. Every dancer, in order to learn and master the true art of dance, we can suppose, is at risk of falling, if she does not survive this power of arrest.

In the relatively mundane space of the theatre this drama of the risk of the dancer's fall is decided by what goes on in the mental confrontation with images. Carolina Bergonzoni has described it well. To suffer the suspension of one's movement and nevertheless keep moving is precisely the task of the dancer, and one which testifies to the contemporaneity of Domenico, she maintains (Bergonzoni 2016, p. 24). However, beyond the theatre this drama of the risk of the fall manifests itself in terms of the threats which madness poses to the subject, and of dreams which turn into nightmares (Agamben 2013, p. 14). For all images are as dangerous as they are potentially emancipative. Fundamentally 
there are two types of image, but common to both kinds of image is the power of arrest. Arrest us is what images do. They force us to look. In looking we know not what form of arrest we will be subject to. For the power of arrest is also of two kinds. There are those images that in arresting us serve to take our time. They seize our gaze and yet give nothing in return. Instead they drain us, hold us, transfix us, deplete us, make us less than we are, and in some cases simply kill us; images that do not return our gaze; images that proffer no real reciprocity to our gaze. The name I give to this class of image is the abyssal image.

Then, there is a second class of image that does quite the opposite. It too is an arresting form of image, but it is an image that transforms us through its operation of arrest. In arresting us it gives us life; an image that startles and shocks, which causes us to desire, to feel, and be affected, as well as any other of a range of potential affects. An image which fascinates us, and which gives back more than we are ever able to give it. So the problem of the life of the image may well be posed in terms of the question of where to look. Indeed, not simply where to look but how to look. For one and the same image may very well contain both powers of arrest at the same time. Whether we live a life of encounter with abyssal or aerial images will in any case determine the nature of the life so lived.

To grasp the life of images we also have to address the power of the gaze, which in its seizure of movement, transforms that which moves, into an image. The gaze, in its operation, terminates the movement of that which is in motion (Lacan 2004, p. 117). The rendering of that which lives, and which in life moves, into an image, is itself a terminal operation. Lacan, long before Agamben bore witness to this 'time of arrest' in dance, described it as 'the fascinatory effect' (Lacan 2004, pp. 117-18). The fascinatory effect is that which 'has the effect of arresting movement and literally, of killing life. At the moment the subject stops, suspending his gesture, he is mortified' (Lacan 2004, p. 118). The gaze, that operation by which we produce images out of life, is essentially an 'anti-life' and 'anti-movement' function (Lacan 2004, p. 118). There is, in other words, a fascism to the gaze, which subtracts life from images. Images in themselves cannot become fascist, until they fascinate, and that power of fascination is only ever latent, without their meeting with a gaze. Dance thus exists at a nexus of relations not only between imagination, movement, life, and madness, but also of fascism.

\section{1. 'Another Political Imagination'}

The navigation of this paradox of the life of the image is fundamental to the task of the construction of what the arch-genealogist Foucault called 'another political imagination' (Foucault 2005, p. 185). For it is only in doing so that we will understand the ways in which imagination can function both as the source of subjection as well as the source of action. It is not a question of choosing imagination over reason, as the romantics would have us choose. Nor is it obviously a question of seeing in imagination the source of human subjection as so many of the modernist traditions in philosophical and especially political thought would have us see. Instead it is a question of negotiating the relation between the two classes of image I can only schematically sketch the nature of here; the abyssal and the aerial. Moreover, it is a question of understanding how these two classes of image function always within the same image at any one time. In other words it is a question of addressing the inherent dangerousness of images with a view to comprehending how the life of the image functions in a consistently vertical movement between abyssal and aerial spaces. Without images, without an understanding of the movement that occurs between these two classes of image especially, we cannot hope to comprehend the ways by which we move between these two forms of space. Images are not, as Henri Lefebvre would have us believe, simply 'fragments of space' empowered with the abilities to fragment space itself (Lefebvre 1991, p. 97). It is not 'the image' that 'kills' (Lefebvre 1991, p. 97), for there is no unitary thing such as 'the image'. Our reception of and movement within spaces themselves are dependent upon images, the ways in which they meet our gaze. The eye is not averse to tactile experience. The problem is to parse the differences between images that kill space and images that create space. In dance this is the problem the dancer herself faces at each moment in which her dance potentially develops. With gesture and the performance of presence she may change the nuance of the space in 
which she acts (Bergonzoni 2016, p. 22). Should she fail the space in which she acts risks collapsing and her performance falls into its abyss. Lefebvre himself noted the importance of dance as a practice endowed with the power to produce space, but was ignorant of how dance deploys images and not simply bodies to do so (Lefebvre 1991, p. 205; see also McCormack 2008).

\section{Fascinance and Fascinum}

Bracha Ettinger approaches an account of this problematic in her development of a concept of what she calls fascinance (2006). Fascinance is what happens to the gaze when it encounters an image that gives life rather than taking it. It is in that sense the opposite effect of what Lacan described in terms of the fascinum. It is the transformational aesthetic effect that occurs in the subject when his or her gaze is returned by the image that fascinates (Ettinger 2006, p. 61). In the fascinum that Lacan described, the gaze is not returned, for whatever reason, and the subject is determined, stopped in its movement, by this event of non-reciprocity of the image; another way of conceiving the aestheticization by which, as Walter Benjamin argued, fascism itself is established (Caygill 1998, pp. 116-17).

In the case of fascinance the image puts the subject into movement, and optimally, transforms it. To explicate her case, Ettinger gives a reading of Marguerite Duras's novel The Ravishing of Lol Stein (1966), the narration of which centers on a dance ball in which the main character, Lol Stein undergoes an encounter with an image which would seem to possess precisely such a potential. The Ravishing of Lol Stein is, as Kimberley Philpot Van Noort has observed, a novel in which 'everyone is dancing' (Van Noort 1997, p. 195). Lol is very definitely there to dance but she is also there to see and bear witness to the performance of another dance, that of Tatiana Karl with her fiancé Michael Richardson. This image, that of Karl and Richardson dancing, contains both powers of fascinum and fascinance, possessing the power to transform Lol from girl to woman as well as to withhold that transformation. As it happens Lol's movement from girl to woman is arrested and the rest of the novel tells the story of her attempts to recreate the same or a similar encounter with an image by which she might complete her passage, by turning fascinum into fascinance, so to speak (Ettinger 2006, pp. 62-63). An encounter with an image whose transformative potential has failed, and the attempts to recreate a comparably endowed image, in order to escape from fascinum into fascinance, is, Ettinger argues, the story of the ravishing of Lol Stein.

How can an image affect such a transformation? How can an image deny its own potential to transform? In the case of Lol, her potential transformation from girl to woman is located in an image of two lovers dancing, a man and a woman. It is for Lol, 'a fascinating image she wants to see again and again' (Ettinger 2006, p. 73). An image not just of a man, but a man who 'in front of the desiring and fascinated gaze of Lol', the girl, is desiring another female figure, a woman, a mother figure, who likewise is fascinated and desiring the man, in representation of the image of Lol as the woman she actually desires to become (Ettinger 2006, pp. 73-74). Lol is, Ettinger argues, not yet ready, as a girl, to love the man in question, and desires only to gaze at the dance-image and become a part of it, 'by the transgressive force of fascination that will include her' (Ettinger 2006, p. 64). But how could such an image possibly perform such a transformation? What is the nature of this 'transgressive force' that Duras portrays and Ettinger identifies in the image in question?

What quality differentiates it from the image that performs the opposite effect? For Ettinger, it is a question of difference not of the image as such, but of affect. This power and difference in affect infiltrates the field of perception and shapes the image such that it becomes, either the purveyor of fascinance or fascinum (Ettinger 2006, p. 67). Either the image welcomes her into it, making its space 'shareable', Ettinger maintains, or it will shut her out, closing its space, fragmenting the potential by which a space in which she, Lol, is implicated, might have become shared. The image here is merely a shutter, which either opens or closes, upon a space, depending on the operation of an affect. The image itself is dead matter, neither animate nor inanimate, immobile, until it is moved, by the power of affect. The gaze of fascinance is, if we follow Ettinger, 'an affective vibration' (Ettinger 2006, p. 85). It allows a 'glimpse at the forever out-of-time-and-space' by which 'the forever-future and the archaic past join in the now of the co-eventing in the Real' and 'transform the old scar or mark' (Ettinger 2006, p. 85). 


\section{The Image of Time}

What is the 'forever out-of-time-and-space' if not the time-image which we encounter in the philosophy of Deleuze? The image, that is to say, of Time itself? Is it not, also the small non-time-space in the very heart of time that we also encounter in the work of Arendt (1993, p. 13)? The potential of dance is to render 'time visible and its forms and continuity sensible' (Burt 2009, p. 447). Ramsay Burt has detailed a number of different contemporary dance performances which function this way including those by Ivana Müller, Xavier Le Roy, and others. Works which not only create time for a belief in the impossible, but which do the seemingly impossible, by giving us an image of time itself (Burt 2009, pp. 445-52). This is a power which theorists, notably Susanne Langer, have credited to other arts, particularly music, in ignorance of the power of dance (Langer 1953, pp. 109-19). Deleuze identified it especially with cinema (Deleuze 1989, 1986). However, in Deleuze's analysis the encounter with this image does not enable movement; instead, it disables. The disablement is only superficial. For the encounter with time-images deepens us, taking us down, from the surfaces of movement on which we are otherwise positioned, in our sensory-motored lives. In doing so it makes us a subject. For subjectivity itself emerges, not in movement as such, but in the gap between a received and an executed movement (Deleuze 1989, p. 47). It is not, as Deleuze argues, 'motor or material, but temporal and spiritual' (Deleuze 1989, p. 47). What is crucial in Deleuze's treatment is that it is the image that generates affect. Affect does not simply enter, infiltrating a field of perception, shaping an image; it is instead the encounter with an image, which produces the affect, and the image of time especially. Affect, according to Deleuze, belongs to the gap, between stimulation and response. In this sense affect inhabits an image, because it is an image that fills that gap. This is what Deleuze called the recollection image (Deleuze 1989, p. 47).

In terms of its movement within time the aerial image is also more complicated than Ettinger's analysis allows us to understand. It is not simply initiatory of a movement from girl to woman in the manner she argues it to be, for it is the cause of a forward backwardness which deepens our relation with the past every bit as much as it renders the future more shallow. The Japanese novelist, Yukio Mishima, understood and conveyed this in his Runaway Horses (2000). There we encounter the character Honda, whose mnemic images of his childhood friend, Kiyoaki, produce a movement that is not from boy to man, but man-boy. When he was young there was but one reality for Honda, while the image of the future was multiple, 'swelling with immense possibilities' (Mishima 2000, p. 7). Now he is old reality takes many forms, and it is the past which seems 'refracted into innumerable possibilities (Mishima 2000, p. 7). Each of his images of his childhood friend, Kiyoaki, contains its own reality, and effectively annuls the real with its weight of presence. Inside of it he moves backwards, in time, opening the past, fragmenting it into its innumerable possibilities, transforming from man to boy. Images of what had occurred became constitutive of what could have occurred, and what could have occurred takes on the form of the more vivid than real. Is this the recollection image that Bergson spoke of and which Deleuze also theorized (Deleuze 1989, p. 47)? No, this is not simply an image that recalls some scene that happened in the past; for this is an image which operates as a function of the future by giving the past all the multiplicity and possibility which futuricity entails. It is not simply that the future becomes impoverished, narrow, on account of the potency of the image of Kiyoaki for Honda. Instead the future gives what it has, in terms of its multiplicity and possibility to the past, such that the past becomes future-full. Honda's future retains the images of Kiyoaki, apparently drawn from the past, such that they make them into 'objects to come' (Deleuze 1989, p. 52).

\section{Choreographing Images and Their Movements}

This is the paradox of the aerial image, and its relationship to movement. It enables an ascent to subjectivity, but it is an ascent that proceeds downwards. This is not to be confused with the movement of descent that Bachelard described when he addresses 'the imaginary fall' (Bachelard 2002, pp. 91-109). Indeed, the somewhat simplistic differentiation between ascending and descending movement upon the vertical axis of imagination that Bachelard proposes has to be revised accordingly. It is not simply 
that there is an upward axis of imagination that is true and a downward axis of imagination that is false (Bachelard 2002, p. 92). Bachelard proposes that up is the only true direction that the imagination is geared toward, while down is a direction we take when present in the order of the real. In contrast one falls high every bit as much as one ascends down. The upward fall is what characterizes the encounter with the aerial image every bit as much as the downward climb characterizes the abyssal image. An upward climb would qualify only the most banal of images, as much as the downward fall.

This movement of the aerial image is not to be confused with choreographies of 'aerial dance'. Aerial dance, as it is known and regarded in performance studies and research emerged sometime around 1960s, and with its roots in land art, is concerned with expressing the deep imbrications of human subjectivity with weather and atmospheres (Rogers 2012, p. 63). Instead the aerial image as I am theorizing it here is concerned with choreographing human defiance of atmospheric limits. Nor however is this movement initiated by the aerial image merely temporal or spiritual in the manner that Deleuze argues it can be understood, once we do away with a motorized or material understanding of movement. It is also political. It is a movement that goes back as much as it goes forwards with a view to operating upon the present, and transforming the real by acting upon it, impregnating it with images drawn from the past, which now take on the future, in a movement which dispels nostalgia, conquers melancholy, is neither happy nor sad, but affective. 'So it is that time reenacts the most curious yet earnest spectacles within the human heart. The past makes its appearance again, with all its mingled dreams and aspirations' (Mishima 2000, p. 29). This spectacle, of the genealogical past made present, future-full with all its dreams and aspirations, ready, now to be realized, is that of the image of a movement by which the subject climbs downward, falling upward, forward back, through time, and into new spaces. Hence, it is that images which appeared dead come back to life and charge us with a life which brings past and future into a relay in the present. The name for this form of life, constituted by a genealogical movement through time and choreographed in and by dance, is imaginal life.

\section{Conclusions}

This paper has outlined a political genealogy of dance. It has traced the way in which dance emerged and became conceptualized as an art, not simply of the body and its movement, as commonly supposed, but an art of struggle with and against the body, and as an art of images and their choreography. This paper has demonstrated this by tracing the consistency of the image of dance itself from one of the earliest works on dance, that of Domenico da Piacenza in the 15th century, through to the 18th century and the work of Noverre, into the 19th century and the work of Fuller. This was then followed by an account of the ways in which the roles of images in dance were subject to discipline in the 20th century, and then more recently by a return of the idea of dance as an art of images in the contemporary era. Inevitably, much more work is needed to flesh out this genealogy in greater detail and with more historical nuance, but nevertheless a foundation is provided here. The paper has also sought to link up the notion of dance as a political art of images with the image of dance in political philosophy, showing how important this image has been to trends within contemporary political philosophy concerned with the problem of what Agamben, Bachelard, Foucault, Badiou, Deleuze, and others have contributed to in terms of what I have called the life of images. Dance and philosophy support each other in the endeavor of operating upon the present and transforming the real by acting upon it, impregnating it with images drawn from the past, which might now take on the future, in a movement which it is the task of political genealogy itself to create-one which dispels nostalgia, conquers melancholy, and is neither happy nor sad, but affective.

Funding: This research received no external funding.

Conflicts of Interest: The author declares no conflicts of interest. 


\section{References}

Agamben, Giorgio. 2013. Nymphs. London: Verso.

Albright, Ann Cooper. 2007. Traces of Light: Absence and Presence in the Work of Loïe Fuller. Middletown: Wesleyan University Press.

Arendt, Hannah. 1993. Between Past and Future. London and New York: Penguin.

Bachelard, Gaston. 2002. Air and Dreams: An Essay on the Imagination of Movement. Dallas: Dallas Institute Publications.

Badiou, Alain. 2005. Handbook of Inaesthetics. Stanford: Stanford University Press.

Beaumont, Cyril W. 2004. 'Introduction' in Jean-Georges Noverre. In Letters on Dancing and Ballets. Alton: Dance Books.

Bergonzoni, Carolina. 2016. Fantasmata and Presence: A Comparison between Domenico da Piacenza (1455) and Simona Bertozzi. Congress on Research in Dance Conference Proceedings 26: 21-26. [CrossRef]

Bleeker, Maaike. 2012. Media Dramaturgies of the Mind: Ivana Müller's Cinematic Choreographies. Performance Research 17: 61-70. [CrossRef]

Braga, Corin. 2010. "Imagination", "imaginaire", "imaginal” Three concepts for defining creative fantasy. Journal for the Study of Religions and Ideologies 6: 16.

Burt, Ramsay. 2004. Genealogy and Dance History: Foucault, Rainer, Bausch and de Keersmaeker. In Of the Presence of the Body: Essays on Dance and Performance Theory. Edited by André Lepecki. Middletown: Wesleyan University Press, pp. 29-45.

Burt, Ramsay. 2009. History, Memory and the Virtual in Current European Dance Practice. Dance Chronicle 32: 442-67. [CrossRef]

Carter, Curtis L. 2000. Improvisation in Dance. The Journal of Aesthetics and Art Criticism 58: 181-90. [CrossRef]

Caygill, Howard. 1998. Walter Benjamin: The Colour of Experience. London and New York: Routledge.

Colebrook, Claire. 2005. How can we tell the Dancer from the Dance? The Subject of Dance and the Subject of Philosophy. Topoi 24: 5-14. [CrossRef]

Cvejić, Bojana. 2015. From Odd Encounters to a Prospective Confluence: Dance-Philosophy. Performance Philosophy 1: 7-23. [CrossRef]

Deleuze, Gilles. 1986. Cinema 1: The Movement Image. London: Continuum.

Deleuze, Gilles. 1989. Cinema 2: The Time-Image. London: Athlone Press.

Dreyer, Katja. 2011. Uberflieger. Available online: http:/ / vimeo.com/19484229 (accessed on 27 June 2018).

Eddy, Martha. 2009. A Brief History of Somatic Practices and Dance: Historical Development of the Field of Somatic Education and its Relationship to Dance. Journal of Dance and Somatic Practices 1: 5-27. [CrossRef]

Ettinger, Bracha L. 2006. Fascinance and the Girl-to-m/Other Matrixial Feminine Difference. In Psychoanalysis and the Image. Edited by Griselda Pollock. Oxford: Blackwell.

Foucault, Michel. 2005. Dialogue between Michel Foucault and Baqir Parham. In Foucault and the Iranian Revolution. Edited by Janet Afary and Kevin B. Anderson. Chicago and London: Chicago University Press, pp. 183-89.

Franko, Mark. 2006. Dance and the Political; States of Exception. Dance Research Journal 38: 3-18. [CrossRef]

Gunning, Tom. 2003. Loïe Fuller and the Art of Motion Body, Light, Electricity, and the Origins of Cinema. In Camera Obscura, Camera Lucida: Essays in Honor of Annette Michelson. Edited by Richard Allen and Malcolm Turvey. Amsterdam: Amsterdam University Press, pp. 75-90.

Jarvinen, Hanna. 2014. Dancing Genius: The Stardom of Vaslav Nijinsky. Basingstoke: Palgrave Macmillan.

Laban, Rudolf. 2011. The Mastery of Movement. Alton: Dance Books.

Lacan, Jacques. 2004. The Four Fundamental Concepts of Psycho-Analysis. London and New York: Karnac.

Langer, Susanne. 1953. Feeling and Form. New York: Charles Scribner's Sons.

Lefebvre, Henri. 1991. The Production of Space. Oxford: Blackwell.

Madden, Richard Robert. 1857. Phantasmata or Illusions or Fanaticism. London: Newby.

Mallarmé, Stéphane. 2001a. Another Dance Study: Settings and the Ballet. In Mallarme in Prose. Edited by Mary Ann Caws. New York: New Directions.

Mallarmé, Stéphane. 2001b. Ballets. In Mallarmé in Prose. Edited by Mary Ann Caws. New York: New Directions.

McCormack, Derek P. 2008. Geographies for Moving Bodies: Thinking, Dancing, Spaces. Geography Compass 2: 1822-36. [CrossRef]

Mishima, Yukio. 2000. Runaway Horses. London: Vintage. 
Müller, Ivana. 2012. While We Were Holding It Together. Available online: https:/ / vimeo.com/23973875 (accessed on 27 June 2018).

Noverre, Jean-Georges. 2004. Letters on Dancing and Ballets. Alton: Dance Books.

Powell, Jocelyn. 1988. Dance and drama in the eighteenth century: David Garrick and Jean Georges Noverre. Word E Image: A Journal of Verbal/Visual Enquiry 4: 678-91.

Ranciere, Jacques. 2013. Aisthesis. London and New York: Verso.

Rogers, Amanda. 2012. Geographies of the Performing Arts: Landscapes, Places and Cities. Geography Compass 6: 60-75. [CrossRef]

Smith, A. William. 1995. Fifteenth Century Dance and Music: Treatises on Music. Hillsdale: Pendragon.

Sommer, Sally R. 1980. Loie Fuller's Art of Music and Light. Dance Chronicle 4: 389-401. [CrossRef]

Thesiger, Sarah. 1973. The Orchestra of Sir John Davies and the Image of Dance. Journal of the Warburg and Courtauld Institutes 36: 277-304. [CrossRef]

Thompson, M. J. 2004. Doing your thing? Trisha Brown's object lesson. Women E Performance: A Journal of Feminist Theory 14: 153-63.

Van Noort, Kimberly Philpot. 1997. The Dance of the Signifier: Jacques Lacan and Marguerite Duras's Le Ravissement De Lol V. Stein. Symposium: A Quarterly Journal in Modern Literatures 51: 186-201. [CrossRef] Welsh, Kariamu. 2004. African Dance. Philadelphia: Chelsea House.

(C) 2018 by the author. Licensee MDPI, Basel, Switzerland. This article is an open access article distributed under the terms and conditions of the Creative Commons Attribution (CC BY) license (http://creativecommons.org/licenses/by/4.0/). 